\title{
Editor's Dedication
}

\section{Liz Elliott}

\section{$\mathrm{O}$}

n September 26,2001, I made a ten-hour round trip to the town of Salmon Arm, a beautiful community at the gateway to interior British Columbia. My travelling companion of the day was Wayne Northey, the Director of M2W2 (Man to Man, Woman to Woman), a prison fellowship agency. Our destination was a memorial celebration of the life of Ruth Morris: long-standing member of the Joumal of Prisoners on Prisons editorial board, relentless activist for social justice, friend, partner, and mother. Ruth died on Monday, September 17,2001 , in the company of family and friends at the age of 67.

I first met Ruth in Toronto in 1981, when our paths crossed through our mutual work. She impressed with her analyses of the problems we faced, and the values to which she held her actions accountable. Once Ruth got a handle on a particular problem, she rolled up her sleeves, put her assets on the line with the support of her husband, Ray, and established a practical resource to address it. She did this many times, creating the Toronto Bail Project, various neighbourhood mediation projects, a halfway house for former prisoners with special needs, and the International Conference on Penal Abolition (ICOPA).

Originally from the state of New York, Ruth Morris lived almost all of her adult life in Toronto, Canada. Grounded in her Quaker beliefs, she strove to live a life that embodied the values necessary for a peaceful, just society. She was a teacher, social worker, writer, and mentor to many. Diagnosed with terminal cancer at the end of the 2000 ICOPA in Toronto, she and Ray accelerated their plans to make their planned retirement move to British Columbia, settling into a new community only five months before she died. Wayne and I pondered during our long journey on how many people could possibly be in attendance at Ruth's memorial, knowing that a subsequent Toronto celebration would include the hundreds of people who shared some part of Ruth's life up to the point of her short stay in Salmon Arm.

Ruth had been busy during those five months. The celebration circle included about 75 family and friends. Person after person stood up to speak of the profound effect Ruth had and continues to have on their lives, often prefacing their thoughts with the astonished caveat that they had only known her a few months, and vowing to take up the battle for social justice. They were particularly honoured that she had included them in a special ceremony in her home where 
she was awarded the Order of Canada. One friend described the scene: Ruth "looked very weary, though her spirit was as strong as ever. She made a typical no-holds-barred statement, in front of our Lieutenant-Governor ..., about justice and the poor, and then sat down to receive her medal - clearly on behalf of the poor and the marginalized."

Ruth would have enjoyed this volume of the Journal of Prisoners on Prisons. Indeed, the issue reflects both her character and her beliefs. Ruth's beliefs are amplified in the writers' macro-analyses of the prison in the context of the "new world order," and in the micro-insights of the effects of prison experience on the individual lives of people she spent her life fighting on behalf. Reflections of her character are found in the black humour, passion, and spirit of our authors' words. We dedicate this issue to the memory of Ruth Morris, in recognition of her lifelong contributions to social and prison justice.

Some editorial board members are moving on to other projects. We thank Rick Alexander and Daniel Dos Santos for their contributions to the Journal over the past few years. We are also sorry to lose the services of Curtis Taylor, who was particularly involved in the formative stages of the $J P P$, providing editing and technical assistance.

New to the editorial board this issue is Jay Jones, who co-edited Volume 11. Jay's interest in cultural criminology, writing skills, and computer savvy are welcome assets to the $J P P$. He is the creator of the new $J P P$ webpage (www.jpp.org), co-editor of this issue, and the author of its introductory essay.

We also welcome back the energetic involvement of Howard Davidson, founder of the $J P P$. Howard is currently editing Volume 13 - a special edition on prison education - with Jon Marc Taylor, as he resumes his significant responsibilities as the journal's co-editor.

Thanks again to our supporters at Canadian Scholars' Press - particularly Althea Prince, Rebecca Conolly, and Jack Wayne - for helping to amplify our writers' words. Creating a wider public space for the voices of the imprisoned has been a long journey. Their belief in this project and efforts in the production and distribution of the JPP have helped us develop the larger audience our writers deserve.

1. Personal e-mail sent from Gerry Ayotte (Pacific Regional Chaplain, Correctional Service of Canada) to Liz Elliott, on Thursday, August 30, 2001. 